Article

\title{
Preliminary Study on the Performance Evaluation of a Light Shelf Based on Reflector Curvature
}

\author{
Heangwoo Lee ${ }^{1} \mathbb{D}$, Janghoo Seo ${ }^{2}$ and Chang-ho Choi ${ }^{3, *}$ \\ 1 College of Design, Sangmyung University, Cheonan-si, Chungcheongnam-do 31066, Korea; 2hw@smu.ac.kr \\ 2 School of Architecture, Kookmin University, Seoul 02707, Korea; seojh@kookmin.ac.kr \\ 3 Department of Architectural Engineering, Kwangwoon University, Seoul 01886, Korea \\ * Correspondence: choi1967@kw.ac.kr; Tel.: +82-2-940-5566
}

Received: 20 August 2019; Accepted: 7 November 2019; Published: 11 November 2019

check for updates

\begin{abstract}
The consumption of lighting energy in buildings continues to rise, and many studies are being conducted to address this problem. As part of such initiatives, research is being performed on light shelves, which are natural lighting systems. However, most prior studies focused on variables for operating flat reflectors and light shelves. This study aims to evaluate the performance of curved light shelves to prove their effectiveness and derive optimal specifications for them. The following conclusions were reached. The optimal light shelf angles for a flat light shelf were found to be $30^{\circ}, 20^{\circ}$, and $20^{\circ}$ for the summer, mid-season, and winter, respectively, and accordingly, a movable light shelf system would be suitable for all three seasons. The optimal light shelf angles for a movable curved light shelf with an arc angle of $60^{\circ}$ were found to be $30^{\circ}, 30^{\circ}$, and $10^{\circ}$ for the summer, mid-season, and winter, respectively. The optimal light shelf angle and arc angle for a fixed-type curved light shelf were found to be $20^{\circ}$ and $60^{\circ}$, respectively. A fixed-type curved light shelf designed according to these optimal specifications can reduce energy consumption by $3.6 \%$ in comparison to a movable flat light shelf. Consequently, the curved light shelf is considered an effective system, and additional studies analyzing various other factors should be carried out in the future.
\end{abstract}

Keywords: light shelf; curvature; performance evaluation; energy saving

\section{Introduction}

Concerns about global warming due to greenhouse gas (GHG) emissions are growing as the use of fossil fuels as energy sources continues to increase in the industrial, transportation, and building sectors [1]. According to a report published by the Global Alliance for Building and Construction in 2017 , the energy used in buildings accounts for $36 \%$ of the entire energy consumption and $39 \%$ of GHG emissions [2]. Thus, a wide variety of research and development (R\&D) and technological developments are being pursued to reduce energy consumption and implement zero-energy technologies in the building sector [3,4]. According to the "2016 Renewable Energy Data Book" published by the US Department of Energy in 2017, the amount of lighting energy used in buildings accounts for $9 \%$ of the total energy consumption of buildings [5], which is the fourth highest after space heating, water heating, and space cooling.

To address the issue of lighting energy consumption in buildings, many studies have been performed on light shelves, which are typical natural daylighting systems attached to windows to reflect external natural light into rooms via a reflector and the ceiling of the indoor space. However, prior studies on the performance of light shelves have been limited in that they only address the use of flat light shelves, which introduce light into a room in just one direction, in a manner similar to that in which a mirror reflects light. Recent studies have addressed this limitation by evaluating the effects of various factors such as the width of the reflector [6] on the efficiency of flat light shelves. 
However, such measures may be inefficient to reduce the energy consumption of the building because they increase the range of motion of the light shelves and require additional energy. In contrast, curved light shelf reflectors may reduce not only lighting energy but also the energy required to operate the light shelf by reducing the influence of external factors such as the sun's altitude, and by introducing diffused light into the room in addition to the natural outside light.

This paper proposes a light shelf with a curved reflector; the effectiveness and the optimal specifications of the proposed light shelf were established by evaluating its performance as a function of its curvature.

\subsection{Light Shelf Concept and Previous Studies}

As shown in Figure 1, a light shelf is a typical natural daylighting system installed on windows that reduces lighting energy by introducing external natural light deep into a room through the use of a reflector and ceiling surface. Further, as shown in Figure 2, a light shelf can improve uniformity by blocking external natural light from directly entering a room through windows [7]. The variables that determine the daylighting performance of a light shelf include its height, angle, and reflectance. The angle of the light shelf is an important factor in its performance. Many studies have been conducted on optimizing the angle of a light shelf to respond to the external environment [8-10], but adjusting the angle of a light shelf requires additional energy for its operation [8]. Light shelves are classified as external or internal, depending on the position of the light shelf [9].

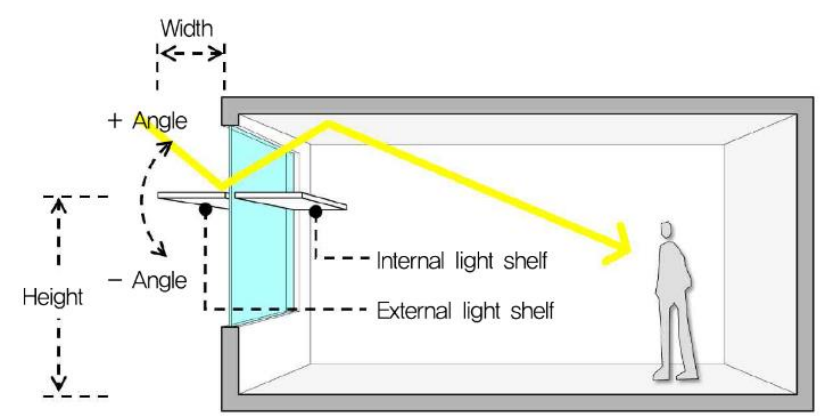

Figure 1. Concept of and variables associated with a light shelf.

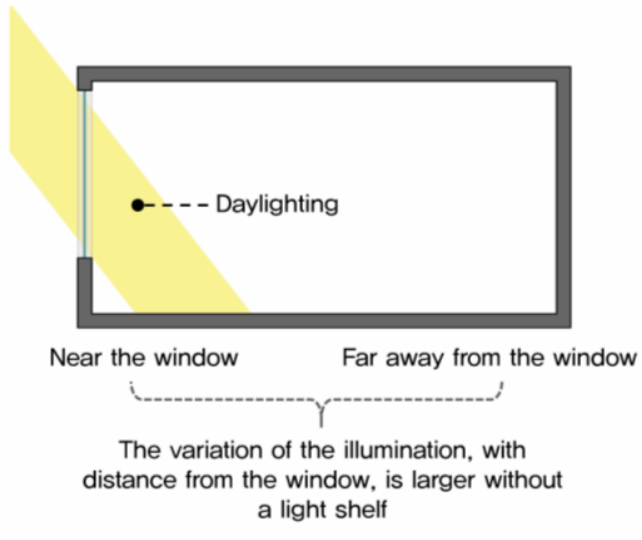

a) Inflow of light without a light shelf

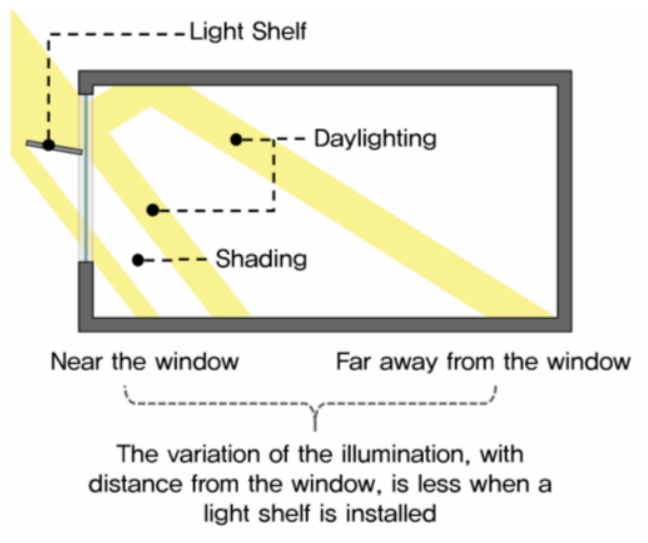

b) Inflow of light with a light shelf installed

Figure 2. Inflow of light with and without a light shelf.

As summarized in Table 1, previous studies on light shelves focus on optimizing the values of variables associated with light shelves to improve their daylighting performance and reduce the energy consumption of the building [6,9-15]. In recent studies, information technologies such as user recognition have been used to improve the daylighting performance of light shelves $[9,10]$. Some other studies combined various building envelope element technologies such as photovoltaics (PV) and 
awnings to reduce building energy consumption [11,12]; however, these studies focused primarily on the use of flat reflectors. To the best of our knowledge, there has been little research and technological development related to curved light shelves. The present study was conducted to evaluate the performance of a curved light shelf and derive its optimal specifications.

Table 1. Previous studies on light shelves for improving daylighting performance and reducing the energy consumption of the building.

\begin{tabular}{ccc}
\hline Author (Publication Year) & $\begin{array}{c}\text { Technology Applied to Improve } \\
\text { Daylighting Performance }\end{array}$ & Shape of Light Shelf Reflector \\
\hline Lee et al. [6] & $\begin{array}{c}\text { Length adjustment through } \\
\text { modularization of light reflectors } \\
\text { Occupant location recognition } \\
\text { technology }\end{array}$ & Flat reflector \\
Lee et al. [8] & $\begin{array}{c}\text { User recognition technology } \\
\text { Combined with PV } \\
\text { Kim et al. [10] }\end{array}$ & Flat reflector \\
Lee et al. [11] & $\begin{array}{c}\text { Light shelf + awning system } \\
\text { Changes in the light shelf angle } \\
\text { and width }\end{array}$ & Flat reflector \\
Moazzeni et al. [13] & $\begin{array}{c}\text { Changes in the light shelf angle } \\
\text { Change in light shelf reflector } \\
\text { material }\end{array}$ & Flat reflector \\
Warrier et al. [14] & Flat reflector \\
Claros et al. [15] & Flat reflector
\end{tabular}

\subsection{Reflection of Light on a Curved Surface}

As shown in Figure 3, a curved surface can reflect light in various directions depending on the point of incidence. Curved light shelves can thereby improve daylighting performance by diffusing light in the process of introducing natural light into a room, as shown in Figure 4. This is because the reflection of light by a curved surface introduces external natural light into a room regardless of the external environmental factors. The reflection of light on a curved surface can be derived by the following method. The light incident on the curved surface assumes a plane tangent to the incident point and derives a normal perpendicular to that surface. The angle formed by this normal and the path of the incident light becomes the angle of incidence, and based on the normal, we can derive the reflected light symmetrical to the incident light. In this study, the natural light entering a room through a curved light shelf was modeled using this method. We used AutoCAD to visualize the inflow of light.

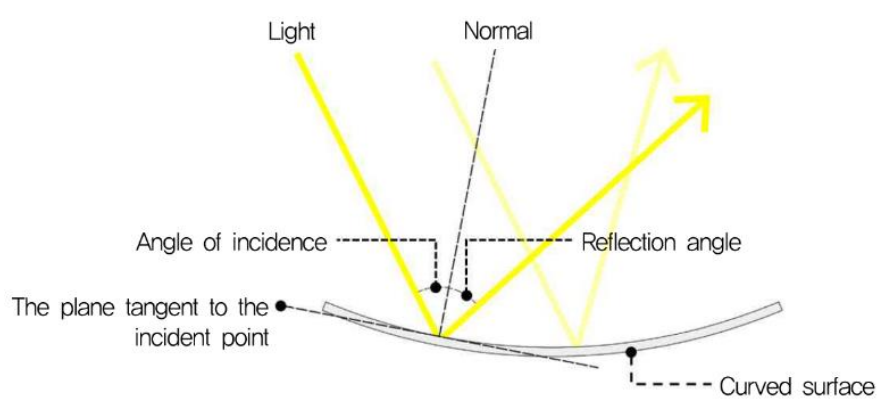

Figure 3. Reflection of light on a curved surface. 


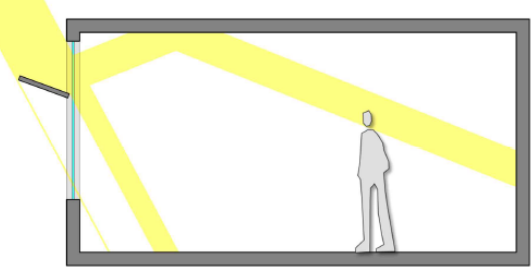

a) Inflow of light using a flat light shelf

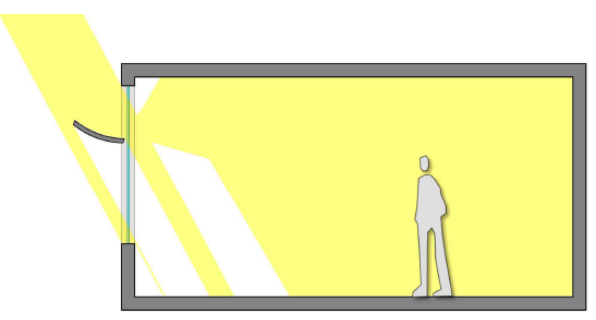

b) Inflow of light using a curved light shelf

Figure 4. The inflow of light achieved using flat and curved light shelves.

\subsection{Consideration of Indoor Optimal Illuminance and Uniformity Ratio}

As listed in Table 2, the indoor illuminance standards of the US, Japan, and Korea were used in this study to evaluate performance based on the curvature of a light shelf [16-18]. Although the indoor illuminance standards in the US, Japan, and Korea differ depending on the nature of the space and the task grade, they each differentiate between the minimum allowed illumination, maximum allowed illumination, and standard allowed illumination in presenting illuminance standards. Therefore, optimal illuminance standards for indoor spaces were established as follows, based on previous studies [19]. The task grade was set to "general" to derive the optimal indoor illuminance, and the overlapping illuminance range of 500-600 lx was derived from the illuminance standards in the US, Japan, and Korea. However, $600 \mathrm{~lx}$ is the maximum allowed illumination prescribed in the illuminance standards of Japan and Korea, and therefore, the optimal indoor illuminance was set to $500 \mathrm{~lx}$ in this study.

Table 2. Optimal indoor illuminance standards by country.

\begin{tabular}{ccccc}
\hline \multirow{2}{*}{$\begin{array}{c}\text { Illuminance Standard } \\
\text { (Country) }\end{array}$} & Task Grade & $\begin{array}{c}\text { Minimum } \\
\text { Allowed } \\
\text { Illumination }\end{array}$ & $\begin{array}{c}\text { Scope (1x) } \\
\text { Standard } \\
\text { Allowed } \\
\text { Illumination }\end{array}$ & $\begin{array}{c}\text { Maximum } \\
\text { Allowed } \\
\text { Illumination }\end{array}$ \\
\hline IES (USA) [16] & General & 500 & 750 & 1000 \\
JIS Z 9110 (Japan) [17] & 300 & 500 & 600 \\
KS A 3011 & 300 & 400 & 600 \\
(Republic of Korea) [18] & & & & \\
\hline
\end{tabular}

To create a pleasant indoor lighting environment, it is important to maintain optimal illuminance and uniform distribution of illuminance [20]. Therefore, the performance of a curved light shelf was evaluated in this study by calculating the uniformity ratio, a measure of the uniformity of indoor illuminance.

\section{Environment for Performance Evaluation}

\subsection{Setting the Variables and Fabricating the Curved Light Shelf}

The effect of the reflector curvature on the performance of a light shelf was evaluated in this study, and thus, the curvature value of the reflector was an important index value in this study. We introduce the concept of an arc angle to quantify the degree of curvature of the reflector. As shown in Figure 5, the arc angle can be derived based on the center point of a circle when creating a circular arc with a length of $l$ on a circumference with a radius $r$. In this study, arc angles were determined as a function of the curvature of the light shelf using AutoCAD. The variables for evaluating the performance of a curved light shelf are summarized in Table 3 . Arc angles from $0^{\circ}-100^{\circ}$, in increments of $20^{\circ}$, were considered. However, only the performances of concave-upward light shelves were evaluated in this study, as concave-downward light shelves may not be suitable for introducing light into rooms (Figure 6). 


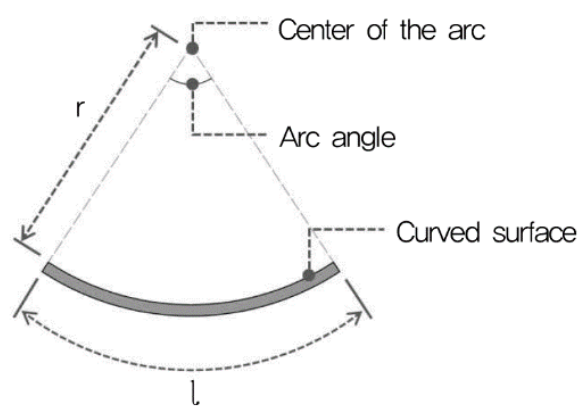

Figure 5. Illustration of the arc angle of a curved surface.

Table 3. Performance evaluation variables for curved light shelves.

\begin{tabular}{cccc}
\hline Variable & Range & Variable & Range \\
\hline Type & External & Width & $0.6 \mathrm{~m}$ \\
Height & $1.8 \mathrm{~m}$ & Angle & $-10^{\circ}, 0^{\circ}, 10^{\circ}, 20^{\circ}, 30^{\circ}$ \\
Reflectance & $85 \%$ (Specular reflection film) & Curvature (arc angle) & $20^{\circ}, 40^{\circ}, 60^{\circ}, 80^{\circ}, 100^{\circ}$ \\
\hline
\end{tabular}

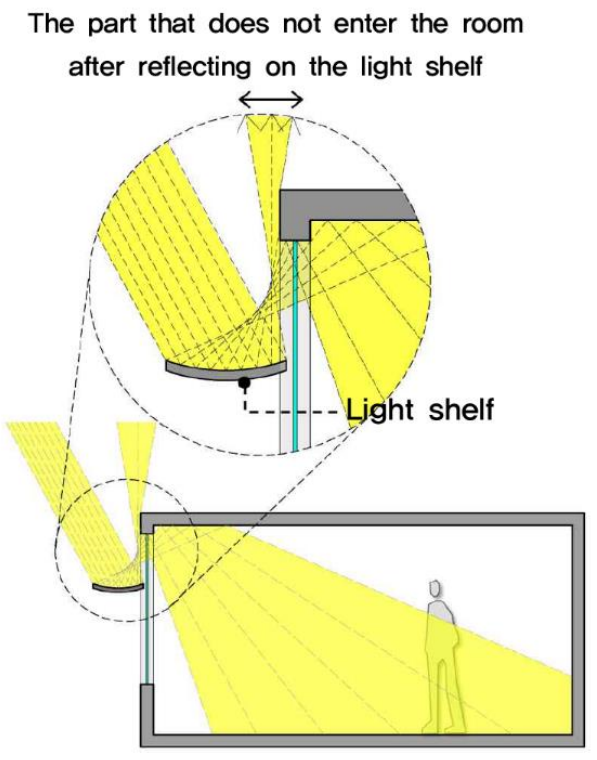

a) Light shelf with a concave-upward curature

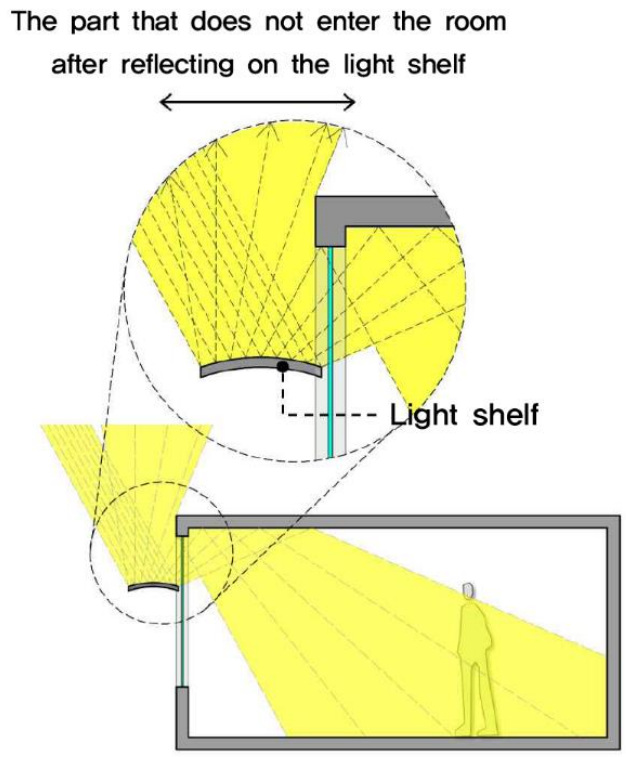

b) Light shelf with a concave-downward curature

Figure 6. The inflow of light according to the curvature of the light shelf.

Figure 7 shows a curved light shelf fabricated in this study for the performance evaluation using the following procedure. We installed a frame to support a light shelf (size: $3 \mathrm{~m} \times 3 \mathrm{~m}$ ) on a window. We fabricated frames to apply the curvature to the light shelf reflector using a three-dimensional (3-D) printer. We installed the light shelf reflector using the light shelf support frame and the curvature application frame. We used a 10-W AC motor as the operating unit to control the angle of the light shelf, based on the load of the light shelf and recommendations from relevant studies [10]. 


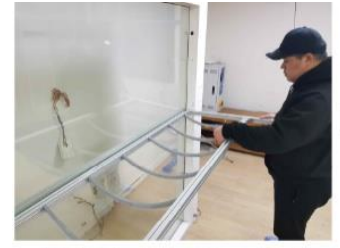

(1) Installing the light

shelf support frame and curvature frame

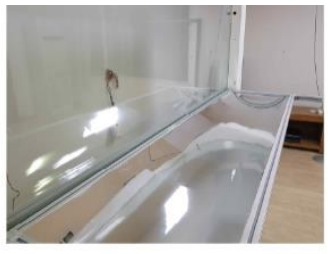

(2) Installing the light shelf reflector

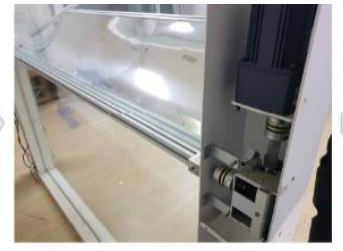

(3) Installing the motor to control the angle of the light shelf

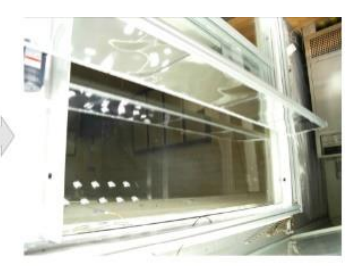

(4) Installing the test bed

Figure 7. Fabrication and installation of a curved light shelf for performance evaluation.

\subsection{Performance Evaluation Environment Setting}

We built the test bed detailed in Table 4 and shown in Figure 8 to evaluate its daylighting performance and reduction in lighting energy consumption as a function of the curvature of the light shelf reflector. The test bed was $4.9 \mathrm{~m} \times 6.6 \mathrm{~m} \times 2.5 \mathrm{~m}$, and the size of the daylighting window on which the light shelf was installed was $1.9 \mathrm{~m} \times 1.7 \mathrm{~m}$. A chamber was built to create an artificial environment outside the window where the curved light shelf was installed to create an external light environment. To simulate the sun, we installed an artificial solar irradiation apparatus that permitted the adjustment of the intensity, height, and angle of the light source. Because of the mechanical characteristics of this apparatus, we only evaluated the performance when the sun was facing south as it was impossible to simulate a solar azimuth. This is a limitation of the performance evaluation procedure used in this study. An artificial solar irradiation apparatus was used because this device is a Class-A apparatus that ensures measurement uniformity in accordance with the American Society of Testing and Materials (ASTM) E927-85 standard, and thus, we were able to create the same external light environment for each case easily and obtain valid results for use in the performance evaluation. Light-emitting diode (LED) lights with eight-level dimming control were installed inside the test bed at four locations, according to the Illuminating Engineering Society (IES)'s four-point method [16] to assess the lighting energy reduction performance achieved. Figure 9 shows the light distribution of the lighting equipment used in this study. We installed an energy monitoring system to measure the consumption of lighting energy. The measurement error rate of the system was within $2 \%$. Based on guidance from relevant studies [21,22], three external light environments were considered in this study: summer, mid-season, and winter. The external illuminance values with respect to time period and meridian altitude are shown in Table 5. The meridian altitude and external illuminance in Table 5 are based on Seoul, Korea, and the external illuminance by the time period were derived on a clear day based on the details provided by a relevant study [11]. 
Table 4. Details of test bed and chamber.

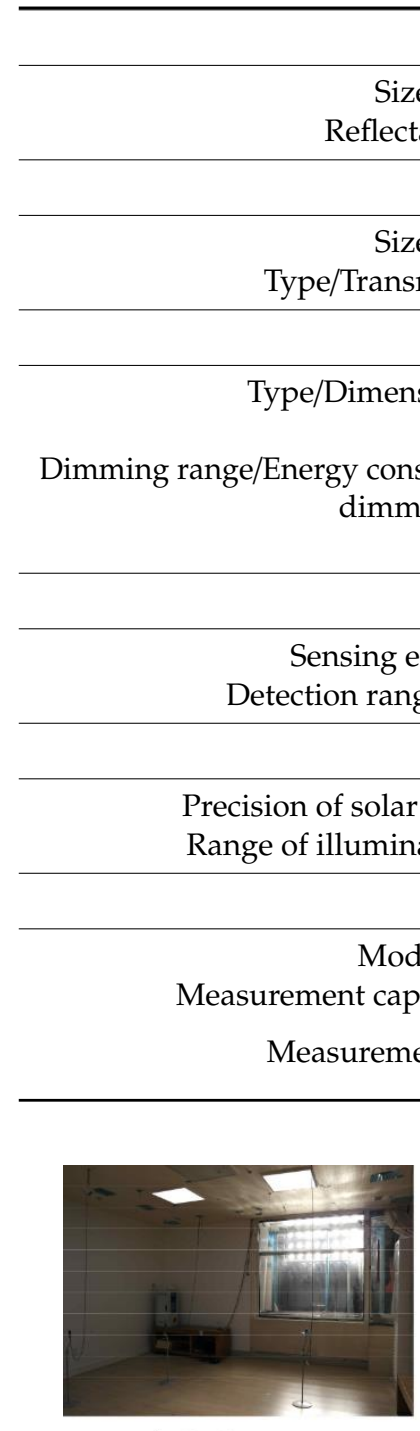

a) Performance evaluation test bed

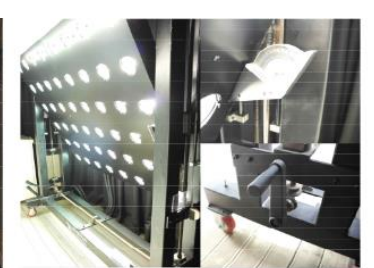

b) Artificial solar irradiation apparatus

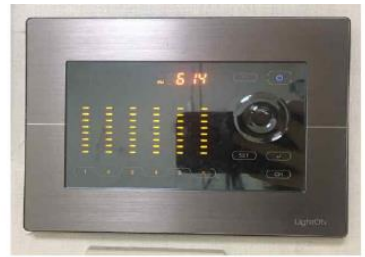

c) Eight-level lighting control
$1.9 \mathrm{~m}(\mathrm{w}) \times 1.7 \mathrm{~m}(\mathrm{~h})$

Double-glazed 12 mm (3 CL + 6 A + 3 CL)/80\%

Lighting

Eight-level dimming (LED type) 4 ea $/ 0.6 \mathrm{~m} \times 0.6 \mathrm{~m}$ 10\%-100\%/12.3 kWh (Level 1), 18.3 kWh (Level 2), $22.0 \mathrm{kWh}$ (Level 3), $27.7 \mathrm{kWh}$ (Level 4), 34.0 kWh (Level 5), $38.5 \mathrm{kWh}$ (Level 6), $42.6 \mathrm{kWh}$ (Level 7), and $50.8 \mathrm{kWh}$ (Level 8)

\section{Illuminance Sensor}

Precision

Silicon photo sensor with filter $0-200,0001 x / \pm 3 \%$

Artificial Solar Light Radiation Apparatus

Grade A (according to ASTM E927-85)

0-80,000 1x/South aspect

\section{Energy Monitoring System}

Single phase $(220 \mathrm{~V}, 1-50 \mathrm{~A}) /$ within $2.0 \%$

Power/voltage/current, real-time, and accumulated amount

Figure 8. Test bed: section and plane.

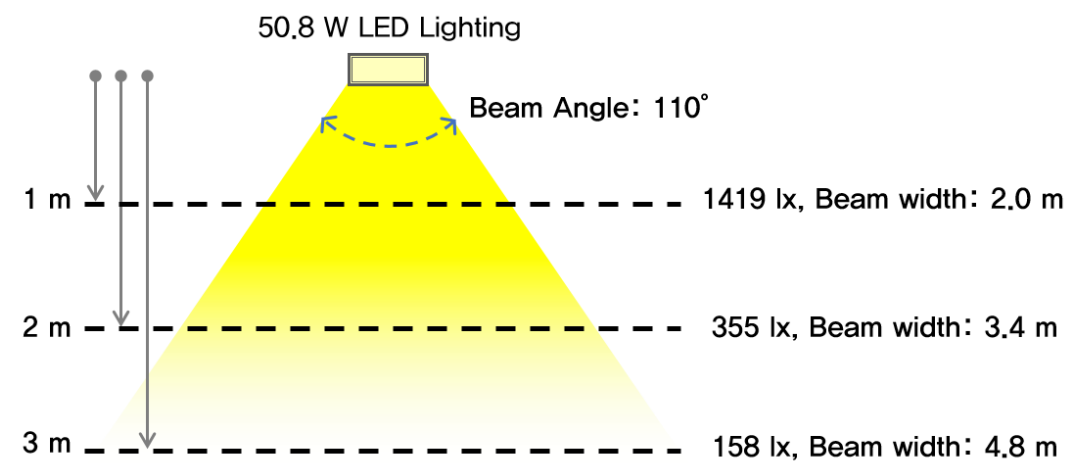

Figure 9. Light distribution and conical illuminance of lighting. 
Table 5. Solar altitude and external illuminance by time period for summer, mid-season, and winter.

\begin{tabular}{ccccccc}
\hline \multirow{2}{*}{ Season } & $\begin{array}{c}\text { Meridian } \\
\text { Altitude }\end{array}$ & \multicolumn{5}{c}{ External Illuminance by Time Period (lx) } \\
\cline { 3 - 6 } & & $\mathbf{1 0 : 0 0 - 1 1 : 0 0}$ & $\mathbf{1 1 : 0 0 - 1 2 : 0 0}$ & $\mathbf{1 2 : 0 0 - 1 3 : 0 0}$ & $\mathbf{1 3 : 0 0 - 1 4 : 0 0}$ & $\mathbf{1 4 : 0 0 - 1 5 : 0 0}$ \\
\hline Summer & 76.5 & $70,000 \mathrm{~lx}$ & $80,000 \mathrm{~lx}$ & $80,000 \mathrm{~lx}$ & $80,000 \mathrm{~lx}$ & $70,000 \mathrm{~lx}$ \\
Middle & 52.5 & $50,000 \mathrm{~lx}$ & $50,000 \mathrm{~lx}$ & $60,000 \mathrm{~lx}$ & $60,000 \mathrm{~lx}$ & $50,000 \mathrm{~lx}$ \\
season & 29.5 & $20,000 \mathrm{~lx}$ & $20,000 \mathrm{~lx}$ & $30,000 \mathrm{~lx}$ & $30,000 \mathrm{~lx}$ & $20,000 \mathrm{~lx}$ \\
Winter & & &
\end{tabular}

As shown in Figure 10, illuminance was measured at 20 locations on a grid to assess the daylighting performance of the lighting shelf and to control the lighting. The illuminance values were measured $0.75 \mathrm{~m}$ above the floor. Based on the findings of a relevant study [23], we measured the average illuminance at a distance of $4.4 \mathrm{~m}$ from the daylighting window.

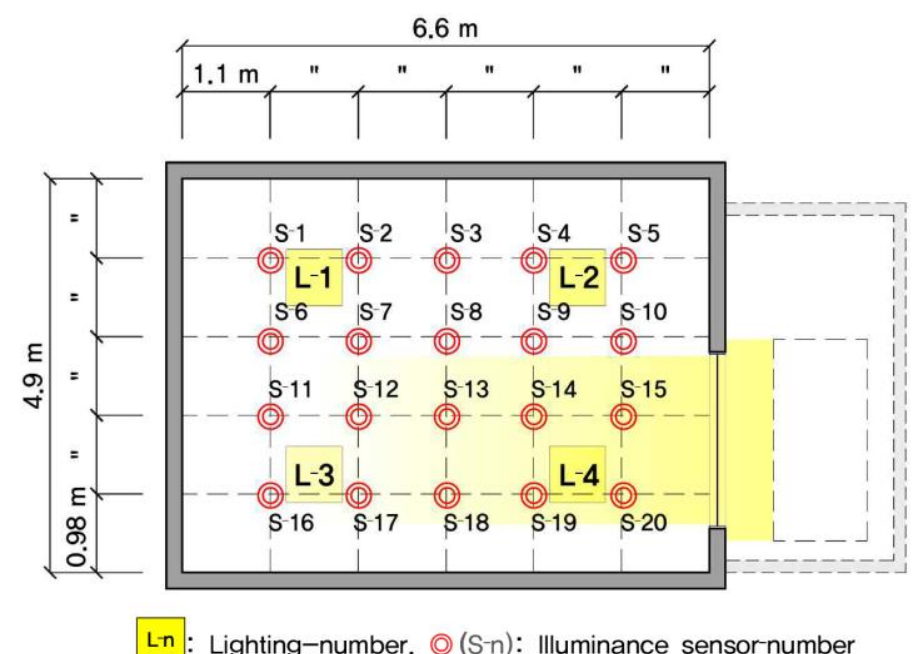

a) Placne and sensor location

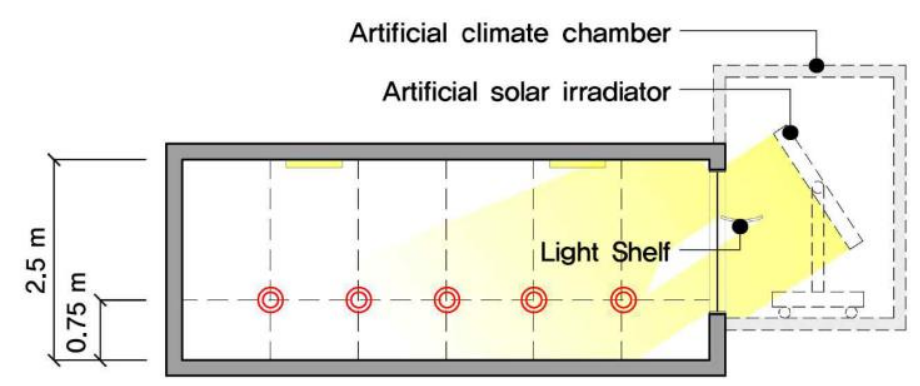

b) Section and sensor location

Figure 10. Test bed: section, plane, and sensor locations.

\subsection{Performance Evaluation Method}

The performance evaluation method used in this study was based on the findings of relevant studies [19,24], and its details are as follows. We evaluated the performance of a flat light shelf and a curved light shelf to confirm the effectiveness of the curved light shelf used in this study. The arc angle of the flat light shelf was $0^{\circ}$. The distribution of indoor illuminance with respect to the curvature angle of the light shelf was analyzed, and based on the results, we determined the indoor uniformity ratio, defined as the minimum illuminance versus the average illuminance. A higher value of the indoor uniformity ratio was considered to be more advantageous in improving the indoor light environment. The lighting energy consumption was calculated as a function of the curvature angle of the light 
shelf, and therefore, we built a light dimming control system with the cooperation of Samsung SDS to maintain the optimal indoor illuminance automatically.

Dimming control was performed according to the following procedure. First, based on the value indicated by the illuminance sensor, i.e., the lowest value of indoor illuminance and depending on the curvature angle of the light shelf, dimming control was performed when the value was less than 500 lx. When the minimum value of the illuminance sensor was less than 500 lx, the dimming level was increased sequentially from the lighting next to the illuminance sensor with the minimum value, until all illuminance sensors reach $500 \mathrm{~lx}$. The lighting dimming level and power consumption corresponding to $500 \mathrm{~lx}$ were used to evaluate the lighting energy reduction performance. For example, if the indoor illuminance analysis of the curved light shelf showed that the illuminance sensor with the minimum illuminance value was sensor no. 1 and that the value was $2001 x$, the lighting control of lighting source no. 1, which was closest to illuminance sensor no. 1, was increased incrementally from OFF to 500 lx. If the value of illuminance sensor no. 1 did not reach 500 lx even after lighting source no. 1 reached level 8, dimming control was performed in the order of the next closest lighting sources such as nos. 3, 2, and 4. Only one day each in summer, mid-season, and winter was considered to determine the lighting energy consumption associated with each. The effectiveness of the curved light shelf was confirmed based on the lighting energy consumption and the uniformity ratio of the light shelf, and the optimal specifications for the curved light shelf were determined. The optimal specifications for a curved light shelf proposed in this study were derived based on the consumption of lighting energy and the indoor uniformity ratio according to the variables used in this study. The reason for this is that the main purpose of installing light shelves is to reduce lighting energy and improve the indoor uniformity ratio as mentioned in Section 1.1. In addition, the manner in which light entered a room as a function of the curvature angle of the light shelf was examined to enhance the understanding of the results of the performance evaluation.

\section{Performance Evaluation Results and Discussion}

The results of our analysis of the daylighting performance of a flat light shelf and a curved light shelf are presented and discussed below.

For a flat light shelf with a curvature angle of $0^{\circ}$, the optimal angles for reducing the energy consumption of the building in summer, mid-season, and winter were $30^{\circ}, 30^{\circ}$, and $20^{\circ}$, respectively, as shown in Table 6. During summer, we could increase the amount of light entering the room by increasing the reflector angle of the flat light shelf from $-10^{\circ}$ to $30^{\circ}$, thereby reducing the lighting energy consumption in the room as shown in Figure 11. However, during mid-season, a flat light shelf with a reflector angle of $30^{\circ}$ introduced natural light into the room by reflection from the reflector rather than the ceiling, as shown in Figure 12. This angle was considered inappropriate because the occupants may experience an uncomfortable glare, which is consistent with the results of a study analyzing the discomfort glare of light shelves [24]. Therefore, the optimal angle of a flat light shelf during mid-season was set to $20^{\circ}$ and reflected in the performance evaluation results. During winter, as shown in Figure 12, there was no light entering the room by reflection from the light shelf when the angle was set to $30^{\circ}$. The rear part of the reflector rather blocked natural light, which was inappropriate for reducing lighting energy, and therefore, this should be considered when designing light shelves. 
Table 6. Performance evaluation results for flat light shelf.

\begin{tabular}{|c|c|c|c|c|c|c|c|}
\hline \multirow{2}{*}{ Season } & \multirow{2}{*}{$\begin{array}{c}\text { Light Shelf } \\
\text { Angle }\end{array}$} & \multirow{2}{*}{$\begin{array}{c}\text { External } \\
\text { Illuminance } \\
(\mathbf{l x})\end{array}$} & \multicolumn{2}{|c|}{ Illumination (lx) } & \multirow{2}{*}{$\begin{array}{c}\text { Uniformity } \\
\text { Ratio }\end{array}$} & \multirow{2}{*}{$\begin{array}{l}\text { Lighting Dimming } \\
\text { Control: Light ID } \\
\text { (Dimming Level) }\end{array}$} & \multirow{2}{*}{$\begin{array}{c}\text { Electricity } \\
\text { Consumption } \\
(\mathrm{kWh})\end{array}$} \\
\hline & & & Min. & Ave. & & & \\
\hline \multirow{10}{*}{ Summer } & \multirow{2}{*}{$-10^{\circ}$} & 80,000 & 70.1 & 356.4 & 0.197 & $1(8)+3(8)+2(5)$ & \multirow{2}{*}{0.712} \\
\hline & & 70,000 & 61.3 & 313.1 & 0.196 & $1(8)+3(8)+2(8)$ & \\
\hline & \multirow[b]{2}{*}{$0^{\circ}$} & 80,000 & 74.3 & 378.0 & 0.197 & $1(8)+3(8)+2(5)$ & \multirow[b]{2}{*}{0.695} \\
\hline & & 70,000 & 65.4 & 331.9 & 0.197 & $1(8)+3(8)+2(7)$ & \\
\hline & \multirow{2}{*}{$10^{\circ}$} & 80,000 & 79.3 & 393.4 & 0.202 & $1(8)+3(8)+2(5)$ & \multirow{2}{*}{0.695} \\
\hline & & 70,000 & 69.2 & 344.0 & 0.201 & $1(8)+3(8)+2(7)$ & \\
\hline & \multirow[b]{2}{*}{$20^{\circ}$} & 80,000 & 82.7 & 397.9 & 0.208 & $1(8)+3(8)+2(4)$ & \multirow[b]{2}{*}{0.668} \\
\hline & & 70,000 & 72.3 & 350.0 & 0.207 & $1(8)+3(8)+2(6)$ & \\
\hline & \multirow{2}{*}{$30^{\circ}$} & 80,000 & 91.4 & 381.2 & 0.240 & $1(8)+3(8)+2(3)$ & \multirow{2}{*}{0.642} \\
\hline & & 70,000 & 79.9 & 332.8 & 0.240 & $1(8)+3(8)+2(5)$ & \\
\hline \multirow{10}{*}{$\begin{array}{l}\text { Mid- } \\
\text { season }\end{array}$} & \multirow{2}{*}{$-10^{\circ}$} & 60,000 & 121.4 & 352.1 & 0.345 & $1(8)+3(7)$ & \multirow{2}{*}{0.492} \\
\hline & & 50,000 & 101.1 & 293.4 & 0.345 & $1(8)+3(8)$ & \\
\hline & \multirow[b]{2}{*}{$0^{\circ}$} & 60,000 & 126.7 & 361.1 & 0.351 & $1(8)+3(6)$ & \multirow[b]{2}{*}{0.483} \\
\hline & & 50,000 & 105.5 & 300.9 & 0.351 & $1(8)+3(8)$ & \\
\hline & \multirow{2}{*}{$10^{\circ}$} & 60,000 & 132.8 & 364.6 & 0.364 & $1(8)+3(5)$ & \multirow{2}{*}{0.450} \\
\hline & & 50,000 & 110.2 & 303.8 & 0.363 & $1(8)+3(7)$ & \\
\hline & \multirow{2}{*}{$20^{\circ}$} & 60,000 & 141.3 & 374.7 & 0.377 & $1(8)+3(5)$ & \multirow[b]{2}{*}{0.450} \\
\hline & & 50,000 & 117.8 & 312.9 & 0.376 & $1(8)+3(7)$ & \\
\hline & \multirow{2}{*}{$30^{\circ}$} & 60,000 & 151.1 & 476.9 & 0.317 & $1(8)+3(4)$ & \multirow{2}{*}{0.425} \\
\hline & & 50,000 & 125.9 & 397.8 & 0.316 & $1(8)+3(6)$ & \\
\hline & & 30,000 & 252.0 & 5003.2 & 0.050 & $1(6)$ & \\
\hline & $-10^{\circ}$ & 20,000 & 167.8 & 3335.5 & 0.050 & $1(8)+3(3)$ & 0.296 \\
\hline & & 30,000 & 258.5 & 5121.4 & 0.050 & $1(6)$ & \\
\hline & $0^{\circ}$ & 20,000 & 172.3 & 3416.3 & 0.050 & $1(8)+3(3)$ & 0.296 \\
\hline & & 30,000 & 268.5 & 5220.8 & 0.051 & $1(5)$ & \\
\hline Winter & $10^{\circ}$ & 20,000 & 179.2 & 3445.7 & 0.052 & $1(8)+3(2)$ & 0.275 \\
\hline & & 30,000 & 273.2 & 5459.2 & 0.050 & $1(4)$ & \\
\hline & $20^{\circ}$ & 20,000 & 181.1 & 3639.5 & 0.050 & $1(8)+3(2)$ & 0.263 \\
\hline & & 30,000 & 250.4 & 5165.2 & 0.048 & $1(6)$ & \\
\hline & $30^{\circ}$ & 20,000 & 169.4 & 3429.2 & 0.049 & $1(8)+3(3)$ & 0.296 \\
\hline
\end{tabular}

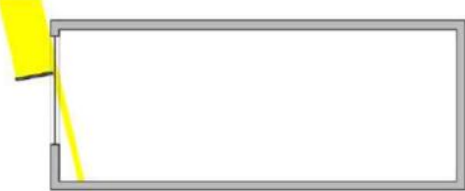

a) Light shelf angle $-10^{\circ}$

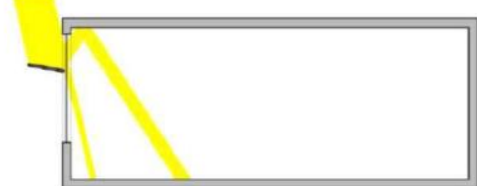

b) Light shelf angle $10^{\circ}$

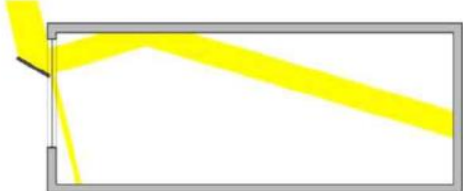

c) Light shelf angle $30^{\circ}$

Figure 11. Inflow of natural light by the light shelf in summer depending on the angle.

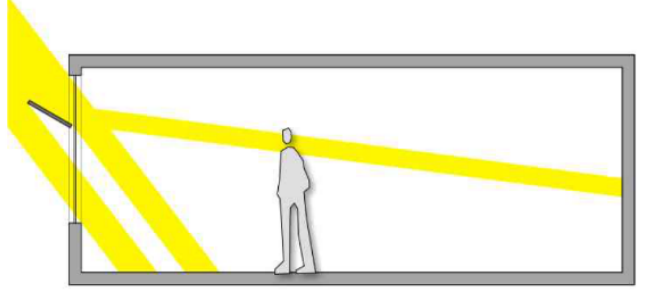

a) The inflow of external natural light by a flat light shelf with an angle of $30^{\circ}$ in mid-season

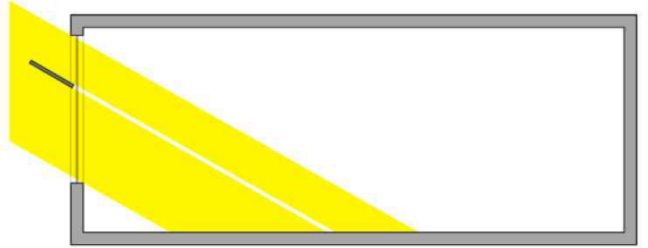

b) The inflow of external natural light by a flat light shelf with an angle of $30^{\circ}$ in winter

Figure 12. Inflow of natural light by the light shelf in mid-season and winter.

Based on the points, the optimal angle of a light shelf varied from season to season, and therefore, a movable light shelf was required to maximize the reduction of lighting energy consumption. In addition, the total consumption of indoor lighting energy was $1.335 \mathrm{kWh}$-according to the environmental settings and the optimal specifications for a flat light shelf derived in this study-as listed in Table 7. Further, we considered the energy to control a movable light shelf, which was set to $0.008 \mathrm{kWh}$, based 
on relevant research findings [10] and the specifications of the motor. Thus, the sum of the lighting energy and the operating energy of the movable light shelf was $1.343 \mathrm{kWh}$.

Table 7. Optimal specifications and lighting energy consumption of the flat light shelf.

\begin{tabular}{cccc}
\hline Season & $\begin{array}{c}\text { Optimal Angle of Light } \\
\text { Shelf }\end{array}$ & $\begin{array}{c}\text { Lighting Energy } \\
\text { Consumption(kWh) }\end{array}$ & $\begin{array}{c}\text { Total Consumption of } \\
\text { Lighting Energy (kWh) }\end{array}$ \\
\hline Summer & $30^{\circ}$ & 0.642 & \\
Middle season & $20^{\circ}$ & 0.450 & 1.355 \\
Winter & $20^{\circ}$ & 0.263 & \\
\hline
\end{tabular}

During summer, a curved light shelf with arc angles of $20^{\circ}, 40^{\circ}$, and $60^{\circ}$ resulted in the same or lower lighting energy consumption compared to a flat light shelf with an arc angle of $0^{\circ}$. Thus, the system was considered effective for reducing lighting energy (Table 8). However, a curved light shelf with an arc angle of $80^{\circ}$ or higher consumed more lighting energy than a flat light shelf, and it was therefore inappropriate for reducing energy consumption. This was because a curved light shelf with an arc angle of $80^{\circ}$ reflected more natural light to the outside than it introduced into the room, as shown in Figure 13. A curved light shelf was also suitable because it improved the indoor uniformity ratio by an average of $6.3 \%$ compared to that of a conventional flat light shelf, as shown in Figure 14 . However, a curved light shelf showed significant improvement in uniformity ratio when the curvature angle was $80^{\circ}$ during summer, but the improvement was insignificant or deteriorated significantly when the angle was $100^{\circ}$. Thus, the optimal specifications for a curved light shelf to reduce lighting energy and improve the indoor uniformity ratio during summer indicated by this study were a light shelf angle of $30^{\circ}$ and an arc angle of $60^{\circ}$.

Table 8. Performance evaluation results for curved light shelf during summer.

\begin{tabular}{|c|c|c|c|c|c|c|c|}
\hline \multicolumn{2}{|c|}{ Light Shelf } & \multirow{2}{*}{$\begin{array}{l}\text { External } \\
\text { Illuminance } \\
\text { (lx) }\end{array}$} & \multicolumn{2}{|c|}{ Illumination (lx) } & \multirow[b]{2}{*}{$\begin{array}{l}\text { Uniformity } \\
\text { Ratio }\end{array}$} & \multirow{2}{*}{$\begin{array}{l}\text { Lighting Dimming } \\
\text { Control: Light ID } \\
\text { (Dimming Level) }\end{array}$} & \multirow{2}{*}{$\begin{array}{c}\text { Electricity } \\
\text { Consumption } \\
(\mathbf{k W h})\end{array}$} \\
\hline Angle & $\begin{array}{l}\text { Curvature } \\
\text { (Arc } \\
\text { Angle) }\end{array}$ & & Min. & Ave. & & & \\
\hline \multirow{10}{*}{-10} & \multirow{2}{*}{20} & 80,000 & 75.7 & 373.8 & 0.203 & $1(8)+3(8)+2(5)$ & \multirow{2}{*}{0.695} \\
\hline & & 70,000 & 65.9 & 327.1 & 0.201 & $1(8)+3(8)+2(7)$ & \\
\hline & \multirow{2}{*}{40} & 80,000 & 78.8 & 383.7 & 0.205 & $1(8)+3(8)+2(5)$ & \multirow{2}{*}{0.695} \\
\hline & & 70,000 & 68.5 & 336.1 & 0.204 & $1(8)+3(8)+2(7)$ & \\
\hline & \multirow{2}{*}{60} & 80,000 & 82.3 & 388.9 & 0.212 & $1(8)+3(8)+2(4)$ & \multirow{2}{*}{0.668} \\
\hline & & 70,000 & 72.1 & 340.2 & 0.212 & $1(8)+3(8)+2(6)$ & \\
\hline & \multirow{2}{*}{80} & 80,000 & 77.5 & 365.2 & 0.212 & $1(8)+3(8)+2(5)$ & \multirow{2}{*}{0.695} \\
\hline & & 70,000 & 67.8 & 319.5 & 0.212 & $1(8)+3(8)+2(7)$ & \\
\hline & \multirow{2}{*}{100} & 80,000 & 75.1 & 355.8 & 0.211 & $1(8)+3(8)+2(5)$ & \multirow{2}{*}{0.695} \\
\hline & & 70,000 & 65.9 & 311.7 & 0.211 & $1(8)+3(8)+2(7)$ & \\
\hline \multirow{10}{*}{0} & \multirow{2}{*}{20} & 80,000 & 78.6 & 385.8 & 0.204 & $1(8)+3(8)+2(5)$ & \multirow{2}{*}{0.695} \\
\hline & & 70,000 & 68.7 & 337.5 & 0.204 & $1(8)+3(8)+2(7)$ & \\
\hline & \multirow{2}{*}{40} & 80,000 & 81.9 & 394.2 & 0.208 & $1(8)+3(8)+2(4)$ & \multirow{2}{*}{0.668} \\
\hline & & 70,000 & 71.5 & 345.0 & 0.207 & $1(8)+3(8)+2(6)$ & \\
\hline & \multirow{2}{*}{60} & 80,000 & 85.7 & 400.8 & 0.214 & $1(8)+3(8)+2(3)$ & \multirow{2}{*}{0.642} \\
\hline & & 70,000 & 75.3 & 350.6 & 0.215 & $1(8)+3(8)+2(5)$ & \\
\hline & \multirow{2}{*}{80} & 80,000 & 80.3 & 372.1 & 0.216 & $1(8)+3(8)+2(4)$ & \multirow{2}{*}{0.668} \\
\hline & & 70,000 & 70.4 & 325.8 & 0.216 & $1(8)+3(8)+2(6)$ & \\
\hline & \multirow{2}{*}{100} & 80,000 & 78.0 & 361.6 & 0.216 & $1(8)+3(8)+2(5)$ & \multirow{2}{*}{0.695} \\
\hline & & 70,000 & 68.3 & 317.8 & 0.215 & $1(8)+3(8)+2(7)$ & \\
\hline
\end{tabular}


Table 8. Cont.

\begin{tabular}{|c|c|c|c|c|c|c|c|}
\hline \multicolumn{2}{|c|}{ Light Shelf } & \multirow{2}{*}{$\begin{array}{l}\text { External } \\
\text { Illuminance } \\
\text { (lx) }\end{array}$} & \multicolumn{2}{|c|}{ Illumination (lx) } & \multirow[b]{2}{*}{$\begin{array}{l}\text { Uniformity } \\
\text { Ratio }\end{array}$} & \multirow{2}{*}{$\begin{array}{l}\text { Lighting Dimming } \\
\text { Control: Light ID } \\
\text { (Dimming Level) }\end{array}$} & \multirow{2}{*}{$\begin{array}{c}\text { Electricity } \\
\text { Consumption } \\
(\mathbf{k W h})\end{array}$} \\
\hline Angle & $\begin{array}{c}\text { Curvature } \\
\text { (Arc } \\
\text { Angle) }\end{array}$ & & Min. & Ave. & & & \\
\hline \multirow{10}{*}{10} & \multirow{2}{*}{20} & 80,000 & 82.3 & 398.2 & 0.207 & $1(8)+3(8)+2(4)$ & \multirow{2}{*}{0.668} \\
\hline & & 70,000 & 72.0 & 348.5 & 0.207 & $1(8)+3(8)+2(6)$ & \\
\hline & \multirow{2}{*}{40} & 80,000 & 85.7 & 410.1 & 0.209 & $1(8)+3(8)+2(3)$ & \multirow{2}{*}{0.642} \\
\hline & & 70,000 & 75.0 & 358.9 & 0.209 & $1(8)+3(8)+2(5)$ & \\
\hline & \multirow{2}{*}{60} & 80,000 & 89.5 & 411.1 & 0.218 & $1(8)+3(8)+2(3)$ & \multirow{2}{*}{0.642} \\
\hline & & 70,000 & 78.3 & 360.4 & 0.217 & $1(8)+3(8)+2(5)$ & \\
\hline & \multirow{2}{*}{80} & 80,000 & 84.1 & 384.3 & 0.219 & $1(8)+3(8)+2(4)$ & \multirow{2}{*}{0.668} \\
\hline & & 70,000 & 74.2 & 338.6 & 0.219 & $1(8)+3(8)+2(6)$ & \\
\hline & \multirow{2}{*}{100} & 80,000 & 81.6 & 372.1 & 0.219 & $1(8)+3(8)+2(4)$ & \multirow{2}{*}{0.668} \\
\hline & & 70,000 & 71.4 & 325.6 & 0.219 & $1(8)+3(8)+2(6)$ & \\
\hline \multirow{10}{*}{20} & \multirow{2}{*}{20} & 80,000 & 85.0 & 402.3 & 0.211 & $1(8)+3(8)+2(3)$ & \multirow{2}{*}{0.642} \\
\hline & & 70,000 & 74.5 & 352.1 & 0.212 & $1(8)+3(8)+2(5)$ & \\
\hline & \multirow{2}{*}{40} & 80,000 & 88.5 & 408.0 & 0.217 & $1(8)+3(8)+2(3)$ & \multirow{2}{*}{0.642} \\
\hline & & 70,000 & 77.5 & 356.9 & 0.217 & $1(8)+3(8)+2(5)$ & \\
\hline & \multirow[b]{2}{*}{60} & 80,000 & 92.3 & 409.1 & 0.226 & $1(8)+3(8)+2(2)$ & \multirow{2}{*}{0.618} \\
\hline & & 70,000 & 80.7 & 358.6 & 0.225 & $1(8)+3(8)+2(4)$ & \\
\hline & \multirow{2}{*}{80} & 80,000 & 86.7 & 378.0 & 0.229 & $1(8)+3(8)+2(3)$ & \multirow{2}{*}{0.642} \\
\hline & & 70,000 & 76.0 & 332.9 & 0.228 & $1(8)+3(8)+2(5)$ & \\
\hline & \multirow{2}{*}{100} & 80,000 & 84.1 & 366.4 & 0.230 & $1(8)+3(8)+2(3)$ & \multirow{2}{*}{0.642} \\
\hline & & 70,000 & 73.7 & 320.7 & 0.230 & $1(8)+3(8)+2(5)$ & \\
\hline \multirow{10}{*}{30} & & 80,000 & 92.9 & 381.0 & 0.244 & $1(8)+3(8)+2(2)$ & \\
\hline & 20 & 70,000 & 81.6 & 333.3 & 0.245 & $1(8)+3(8)+2(4)$ & 0.618 \\
\hline & & 80,000 & 95.5 & 382.8 & 0.249 & $1(8)+3(8)+2(2)$ & \\
\hline & 40 & 70,000 & 83.6 & 334.9 & 0.250 & $1(8)+3(8)+2(4)$ & 0.618 \\
\hline & & 80,000 & 97.8 & 374.0 & 0.261 & $1(8)+3(8)+2(1)$ & \\
\hline & 60 & 70,000 & 85.6 & 328.2 & 0.261 & $1(8)+3(8)+2(3)$ & 0.589 \\
\hline & & 80,000 & 90.0 & 340.4 & 0.264 & $1(8)+3(8)+2(3)$ & \\
\hline & 80 & 70,000 & 78.8 & 300.3 & 0.262 & $1(8)+3(8)+2(5)$ & 0.642 \\
\hline & & 80,000 & 88.1 & 336.0 & 0.262 & $1(8)+3(8)+2(3)$ & \\
\hline & 100 & 70,000 & 76.9 & 294.6 & 0.261 & $1(8)+3(8)+2(5)$ & 0.642 \\
\hline
\end{tabular}

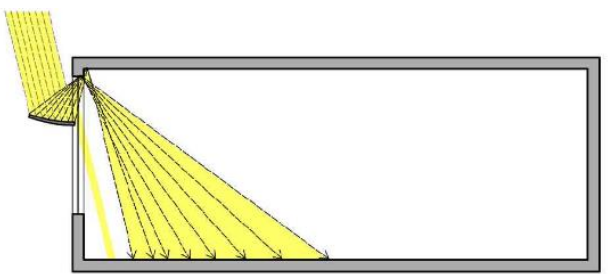

a) The inflow of light by installing a light shelf with an arc angle of $20^{\circ}$

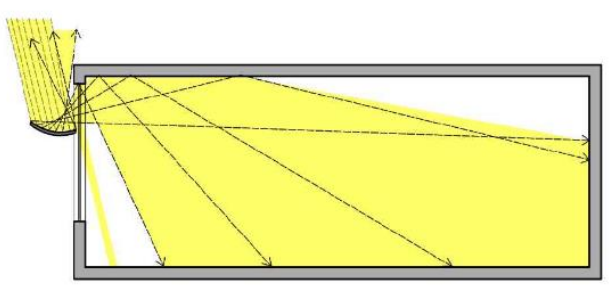

c) The inflow of light by installing a light shelf with an arc angle of $60^{\circ}$

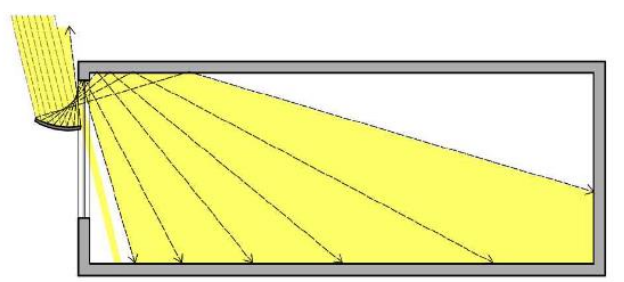

b) The inflow of light by installing a light shelf with an arc angle of $40^{\circ}$

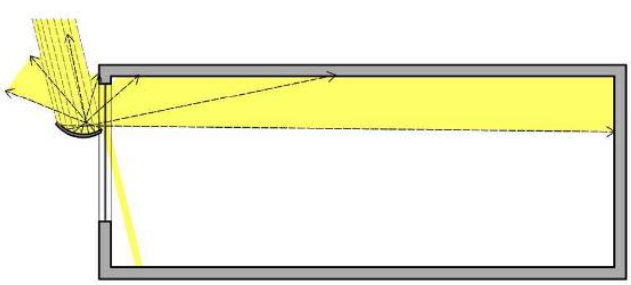

d) The inflow of light by installing a light shelf with an arc angle of $80^{\circ}$

Figure 13. Inflow of light achieved by a curved light shelf during summer depending on the arc angle. 


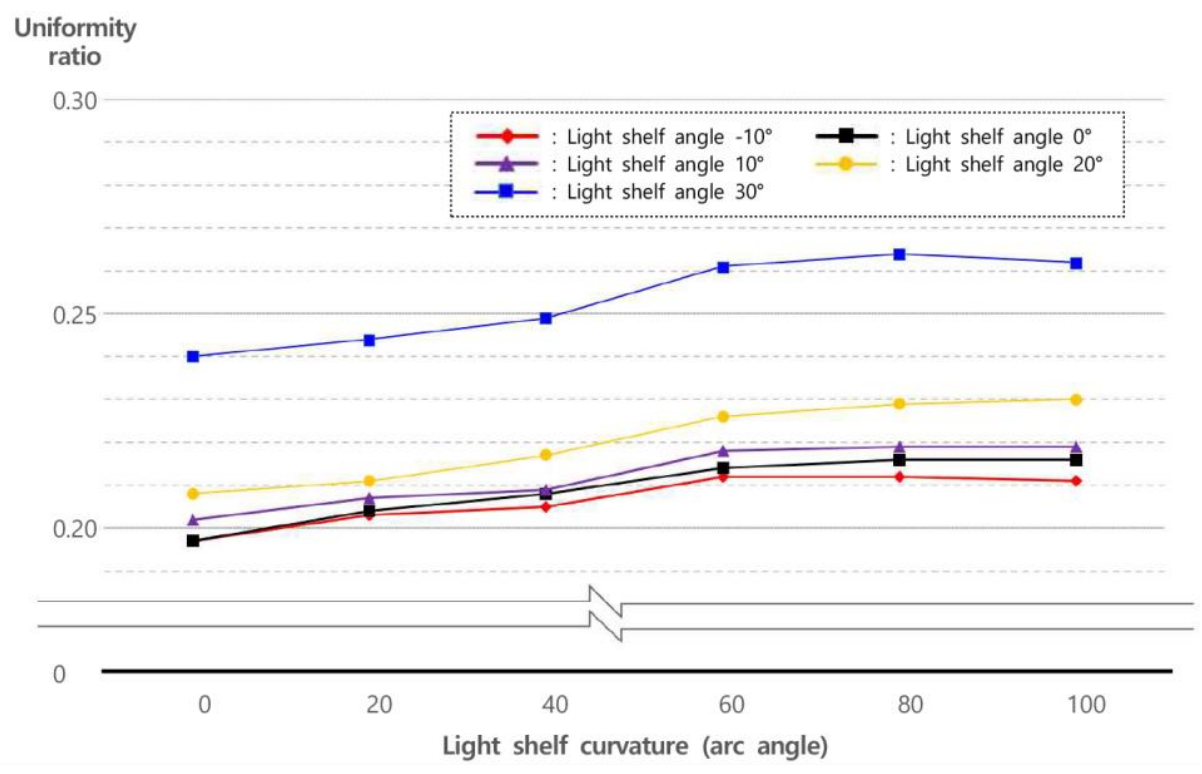

Figure 14. Uniformity ratio versus light shelf angle and arc angle during summer (external illuminance: 80,000 lx).

During mid-season, a curved light shelf showed different results depending on the light shelf angle and arc angle, as shown in Table 9; however, the system was effective in reducing lighting energy when the arc angle was $40^{\circ}$. This means that the daylighting performance cannot be improved by simply increasing the curvature of the light shelf. As shown in Figure 15, the uniformity ratio increased until the arc angle reaches $40^{\circ}$ during the mid-season, but it decreased beyond $60^{\circ}$. Further, this showed that simply increasing the curvature of a light shelf reflector does not improve its performance. During mid-season, a curved light shelf with an angle of $30^{\circ}$ effectively resolved the issue of uncomfortable glare due to light diffusion into the room by reflecting natural light onto the ceiling (Figure 15). In addition, as shown in Figure 16, a flat light shelf with an angle of $30^{\circ}$ exhibited a low uniformity ratio, whereas a curved light shelf exhibited a better uniformity ratio even when the angle was $30^{\circ}$. Thus, curved light shelves could reduce the discomfort caused by glare by diffusing the external natural light, whereas flat light shelves only produce mirror reflections. In summary, the optimal values for a curved light shelf during mid-season were found to be a light shelf angle of $30^{\circ}$ and an arc angle of $40^{\circ}$. 
Table 9. Performance evaluation results for curved light shelf during mid-season.

\begin{tabular}{|c|c|c|c|c|c|c|c|}
\hline \multicolumn{2}{|c|}{ Light Shelf } & \multirow{2}{*}{$\begin{array}{l}\text { External } \\
\text { Illuminance } \\
\quad(\mathbf{l x})\end{array}$} & \multicolumn{2}{|c|}{ Illumination (lx) } & \multirow[b]{2}{*}{$\begin{array}{l}\text { Uniformity } \\
\text { Ratio }\end{array}$} & \multirow{2}{*}{$\begin{array}{l}\text { Lighting Dimming } \\
\text { Control: Light ID } \\
\text { (Dimming Level) }\end{array}$} & \multirow[b]{2}{*}{$\begin{array}{c}\text { Electricity } \\
\text { Consumption } \\
\text { (kWh) }\end{array}$} \\
\hline Angle & $\begin{array}{l}\text { Curvature } \\
\text { (Arc } \\
\text { Angle) }\end{array}$ & & Min. & Ave. & & & \\
\hline \multirow{10}{*}{-10} & \multirow{2}{*}{20} & 60,000 & 124.2 & 338.8 & 0.367 & $1(8)+3(7)$ & \multirow{2}{*}{0.492} \\
\hline & & 50,000 & 103.5 & 282.3 & 0.367 & $1(8)+3(8)$ & \\
\hline & \multirow{2}{*}{40} & 60,000 & 135.5 & 353.1 & 0.384 & $1(8)+3(6)$ & \multirow{2}{*}{0.459} \\
\hline & & 50,000 & 113.0 & 294.3 & 0.384 & $1(8)+3(7)$ & \\
\hline & \multirow{2}{*}{60} & 60,000 & 133.4 & 360.2 & 0.370 & $1(8)+3(6)$ & \multirow{2}{*}{0.483} \\
\hline & & 50,000 & 111.2 & 300.2 & 0.370 & $1(8)+3(8)$ & \\
\hline & \multirow{2}{*}{80} & 60,000 & 132.6 & 391.2 & 0.339 & $1(8)+3(6)$ & \multirow{2}{*}{0.483} \\
\hline & & 50,000 & 110.5 & 326.1 & 0.339 & $1(8)+3(8)$ & \\
\hline & \multirow{2}{*}{100} & 60,000 & 132.1 & 400.0 & 0.330 & $1(8)+3(6)$ & \multirow[b]{2}{*}{0.483} \\
\hline & & 50,000 & 110.1 & 333.6 & 0.330 & $1(8)+3(8)$ & \\
\hline \multirow{10}{*}{0} & \multirow[b]{2}{*}{20} & 60,000 & 129.6 & 346.4 & 0.374 & $1(8)+3(6)$ & \\
\hline & & 50,000 & 108.2 & 288.7 & 0.375 & $1(8)+3(8)$ & 0.483 \\
\hline & & 60,000 & 141.4 & 362.3 & 0.390 & $1(8)+3(5)$ & \\
\hline & 40 & 50,000 & 118.0 & 301.9 & 0.391 & $1(8)+3(7)$ & 0.450 \\
\hline & & 60,000 & 139.0 & 368.3 & 0.377 & $1(8)+3(5)$ & \\
\hline & 60 & 50,000 & 115.8 & 306.9 & 0.377 & $1(8)+3(7)$ & 0.450 \\
\hline & & 60,000 & 138.5 & 401.2 & 0.345 & $1(8)+3(5)$ & \\
\hline & 80 & 50,000 & 115.4 & 334.3 & 0.345 & $1(8)+3(7)$ & 0.450 \\
\hline & & 60,000 & 137.8 & 410.3 & 0.336 & $1(8)+3(5)$ & \\
\hline & 100 & 50,000 & 114.8 & 341.9 & 0.336 & $1(8)+3(7)$ & 0.450 \\
\hline & & 60,000 & 136.0 & 349.9 & 0.389 & $1(8)+3(6)$ & \\
\hline & 20 & 50,000 & 113.3 & 291.6 & 0.389 & $1(8)+3(7)$ & 0.459 \\
\hline & & 60,000 & 148.1 & 364.6 & 0.406 & $1(8)+3(5)$ & \\
\hline & 40 & 50,000 & 123.5 & 303.8 & 0.406 & $1(8)+3(7)$ & 0.450 \\
\hline & & 60,000 & 145.7 & 371.9 & 0.392 & $1(8)+3(5)$ & \\
\hline 10 & 60 & 50,000 & 121.4 & 309.9 & 0.392 & $1(8)+3(7)$ & 0.450 \\
\hline & & 60,000 & 145.1 & 405.3 & 0.358 & $1(8)+3(5)$ & \\
\hline & 80 & 50,000 & 120.9 & 337.7 & 0.358 & $1(8)+3(7)$ & 0.450 \\
\hline & & 60,000 & 144.5 & 414.3 & 0.349 & $1(8)+3(5)$ & \\
\hline & 100 & 50,000 & 120.4 & 345.3 & 0.349 & $1(8)+3(7)$ & 0.450 \\
\hline & & 60,000 & 144.4 & 366.7 & 0.394 & $1(8)+3(5)$ & \\
\hline & 20 & 50,000 & 120.5 & 305.6 & 0.394 & $1(8)+3(7)$ & 0.450 \\
\hline & & 60,000 & 157.7 & 382.2 & 0.413 & $1(8)+3(4)$ & \\
\hline & 40 & 50,000 & 131.4 & 318.6 & 0.412 & $1(8)+3(6)$ & 0.425 \\
\hline 20 & 60 & 60,000 & 155.0 & 389.9 & 0.398 & $1(8)+3(4)$ & 0105 \\
\hline$\angle 0$ & 60 & 50,000 & 129.2 & 324.9 & 0.398 & $1(8)+3(6)$ & 0.425 \\
\hline & 80 & 60,000 & 154.4 & 424.6 & 0.364 & $1(8)+3(4)$ & \\
\hline & 80 & 50,000 & 128.7 & 353.8 & 0.364 & $1(8)+3(6)$ & 0.425 \\
\hline & & 60,000 & 153.7 & 434.2 & 0.354 & $1(8)+3(4)$ & \\
\hline & 100 & 50,000 & 128.4 & 361.8 & 0.355 & $1(8)+3(6)$ & 0.425 \\
\hline & & 60,000 & 154.6 & 390.8 & 0.396 & $1(8)+3(4)$ & \\
\hline & 20 & 50,000 & 128.8 & 325.7 & 0.396 & $1(8)+3(6)$ & 0.425 \\
\hline & & 60,000 & 168.6 & 412.4 & 0.409 & $1(8)+3(3)$ & \\
\hline & 40 & 50,000 & 140.5 & 343.7 & 0.409 & $1(8)+3(5)$ & 0.400 \\
\hline 30 & & 60,000 & 165.8 & 415.5 & 0.399 & $1(8)+3(3)$ & \\
\hline 30 & 60 & 50,000 & 138.2 & 346.5 & 0.399 & $1(8)+3(5)$ & 0.400 \\
\hline & & 60,000 & 165.1 & 452.5 & 0.365 & $1(8)+3(3)$ & \\
\hline & 80 & 50,000 & 137.6 & 377.1 & 0.365 & $1(8)+3(6)$ & 0.414 \\
\hline & & 60,000 & 164.4 & 462.9 & 0.355 & $1(8)+3(3)$ & \\
\hline & 100 & 50,000 & 137.2 & 385.8 & 0.356 & $1(8)+3(6)$ & 0.414 \\
\hline
\end{tabular}




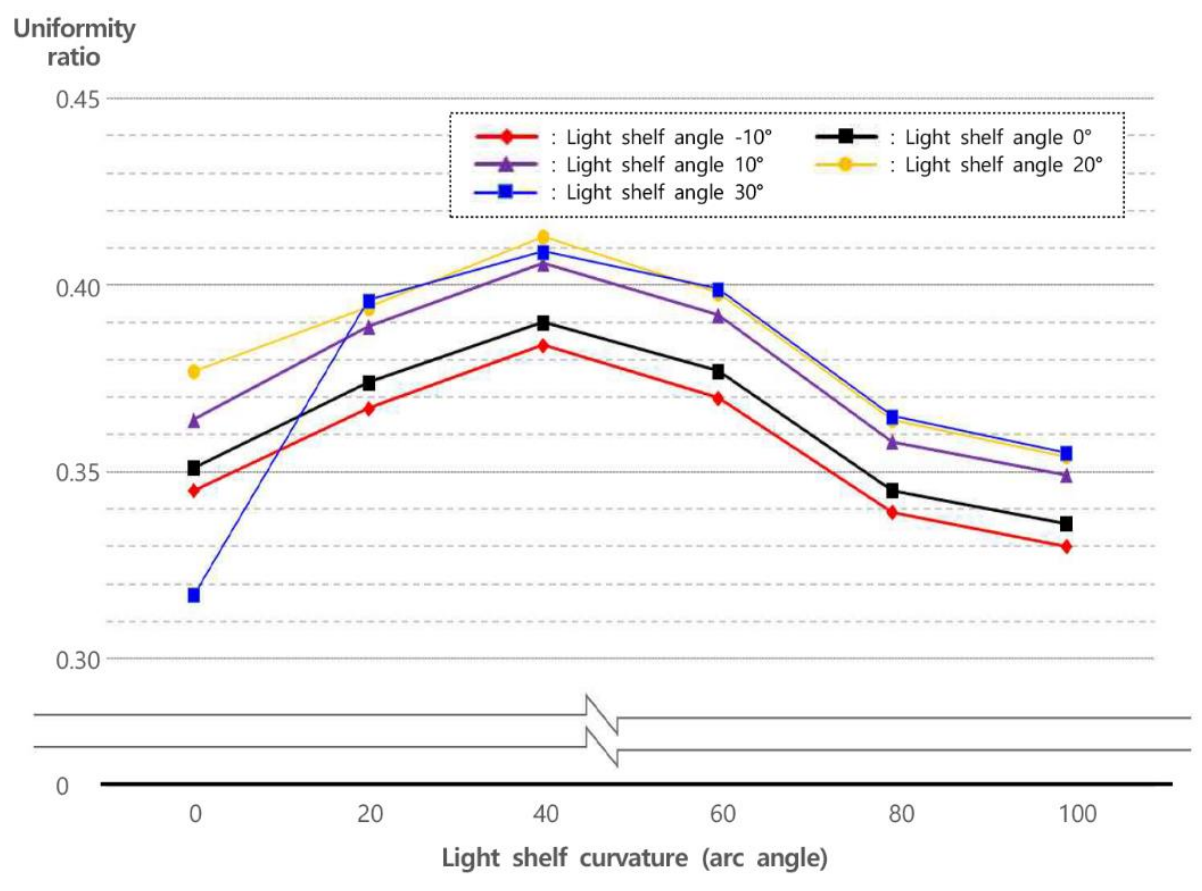

Figure 15. Uniformity ratio versus light shelf angle and arc angle during mid-season.

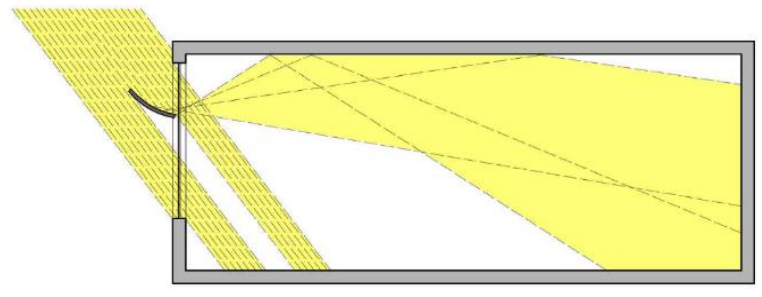

a) Curved light shelf with an arc angle of $20^{\circ}$

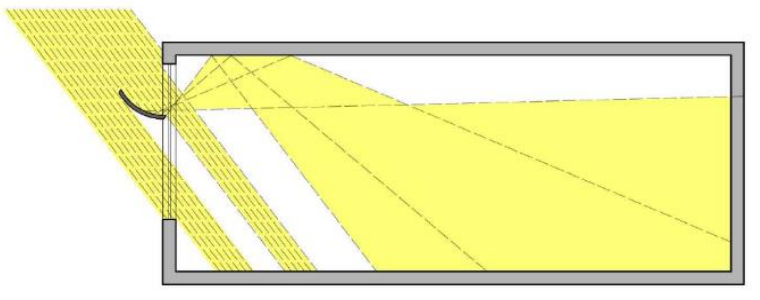

b) Curved light shelf with an arc angle of $40^{\circ}$

Figure 16. Inflow of light achieved by a light shelf with an angle of $30^{\circ}$ during mid-season.

A curved light shelf was less effective in reducing lighting energy consumption than a flat light shelf during winter (Table 10). This was because the range of blocking natural light increased because the thickness of the light shelf increased at lower solar altitudes and curvatures during winter as shown in Figure 17. In addition, a curved light shelf was less effective in improving the indoor uniformity ratio than a flat light shelf, and a curved light shelf with a light shelf angle of $-10^{\circ}$ and a curvature of $30^{\circ}$ decreased the indoor uniformity ratio. This should be considered when designing light shelves. Moreover, since the average indoor illuminance during winter exceeds the maximum allowed indoor illuminance listed in Table 2, additional shading devices such as blinds and louvers will be necessary. Based on these findings, the optimal specifications for a curved light shelf during winter were found to be a light shelf angle of $20^{\circ}$ and arc angles of $20^{\circ}, 40^{\circ}$, or $60^{\circ}$, but it would be better to remove the light shelf. 
Table 10. Performance evaluation results for curved light shelf during winter.

\begin{tabular}{|c|c|c|c|c|c|c|c|}
\hline \multicolumn{2}{|c|}{ Light Shelf } & \multirow{2}{*}{$\begin{array}{l}\text { External } \\
\text { Illuminance } \\
\quad(\mathbf{l x})\end{array}$} & \multicolumn{2}{|c|}{ Illumination (lx) } & \multirow{2}{*}{$\begin{array}{l}\text { Uniformity } \\
\text { Ratio }\end{array}$} & \multirow{2}{*}{$\begin{array}{l}\text { Lighting Dimming } \\
\text { Control: Light ID } \\
\text { (Dimming Level) }\end{array}$} & \multirow[b]{2}{*}{$\begin{array}{c}\text { Electricity } \\
\text { Consumption } \\
\text { (kWh) }\end{array}$} \\
\hline Angle & $\begin{array}{l}\text { Curvature } \\
\text { (Arc } \\
\text { Angle) }\end{array}$ & & Min. & Ave. & & & \\
\hline \multirow{10}{*}{-10} & \multirow{2}{*}{20} & 30,000 & 250.7 & 5052.8 & 0.050 & 1(6) & \multirow{2}{*}{0.296} \\
\hline & & 20,000 & 167.3 & 3372.5 & 0.050 & $1(8)+3(3)$ & \\
\hline & \multirow{2}{*}{40} & 30,000 & 249.3 & 5047.2 & 0.049 & $1(6)$ & \multirow{2}{*}{0.296} \\
\hline & & 20,000 & 166.4 & 3364.8 & 0.049 & $1(8)+3(3)$ & \\
\hline & \multirow{2}{*}{60} & 30,000 & 245.7 & 5029.6 & 0.049 & $1(6)$ & \multirow[b]{2}{*}{0.296} \\
\hline & & 20,000 & 163.6 & 3353.1 & 0.049 & $1(8)+3(3)$ & \\
\hline & \multirow{2}{*}{80} & 30,000 & 241.1 & 5019.2 & 0.048 & $1(7)$ & \multirow{2}{*}{0.304} \\
\hline & & 20,000 & 160.7 & 3346.1 & 0.048 & $1(8)+3(3)$ & \\
\hline & \multirow{2}{*}{100} & 30,000 & 237.5 & 5005.4 & 0.047 & $1(7)$ & \multirow[b]{2}{*}{0.321} \\
\hline & & 20,000 & 158.3 & 3336.2 & 0.047 & $1(8)+3(4)$ & \\
\hline \multirow{10}{*}{0} & \multirow[b]{2}{*}{20} & 30,000 & 262.2 & 5188.0 & 0.051 & 1(5) & \\
\hline & & 20,000 & 174.8 & 3458.4 & 0.051 & $1(8)+3(3)$ & 0.287 \\
\hline & & 30,000 & 270.4 & 5172.6 & 0.052 & $1(5)$ & \\
\hline & 40 & 20,000 & 180.3 & 3448.4 & 0.052 & $1(8)+3(2)$ & 0.275 \\
\hline & & 30,000 & 274.8 & 5269.9 & 0.052 & $1(4)$ & \\
\hline & 60 & 20,000 & 183.2 & 3513.9 & 0.052 & $1(8)+3(2)$ & 0.263 \\
\hline & & 30,000 & 265.1 & 5252.3 & 0.050 & $1(5)$ & \\
\hline & 80 & 20,000 & 176.7 & 3501.5 & 0.050 & $1(8)+3(2)$ & 0.275 \\
\hline & & 30,000 & 260.0 & 5207.7 & 0.050 & $1(5)$ & \\
\hline & 100 & 20,000 & 173.1 & 3472.1 & 0.050 & $1(8)+3(3)$ & 0.287 \\
\hline & & 30,000 & 271.2 & 5235.8 & 0.052 & $1(5)$ & \\
\hline & 20 & 20,000 & 180.7 & 3491.5 & 0.052 & $1(8)+3(2)$ & 0.275 \\
\hline & 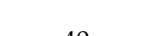 & 30,000 & 276.4 & 5194.4 & 0.053 & $1(4)$ & \\
\hline & 40 & 20,000 & 184.5 & 3463.9 & 0.053 & $1(8)+3(2)$ & 0.263 \\
\hline & & 30,000 & 282.8 & 5220.3 & 0.054 & $1(4)$ & \\
\hline 10 & 60 & 20,000 & 188.9 & 3481.2 & 0.054 & $1(8)+3(2)$ & 0.263 \\
\hline & & 30,000 & 266.6 & 5163.1 & 0.052 & $1(5)$ & \\
\hline & 80 & 20,000 & 177.7 & 3441.1 & 0.052 & $1(8)+3(3)$ & 0.287 \\
\hline & & 30,000 & 263.4 & 5136.1 & 0.051 & $1(5)$ & \\
\hline & 100 & 20,000 & 175.6 & 3423.1 & 0.051 & $1(8)+3(3)$ & 0.287 \\
\hline & & 30,000 & 278.1 & 5486.5 & 0.051 & $1(4)$ & \\
\hline & 20 & 20,000 & 185.4 & 3657.7 & 0.051 & $1(8)+3(2)$ & 0.263 \\
\hline & & 30,000 & 281.7 & 5502.9 & 0.051 & $1(4)$ & \\
\hline & 40 & 20,000 & 187.8 & 3668.6 & 0.051 & $1(8)+3(2)$ & 0.263 \\
\hline 20 & & 30,000 & 280.9 & 5458.7 & 0.051 & $1(4)$ & 0263 \\
\hline 20 & 60 & 20,000 & 187.3 & 3639.1 & 0.051 & $1(8)+3(2)$ & 0.263 \\
\hline & & 30,000 & 271.8 & 5524.7 & 0.049 & $1(5)$ & \\
\hline & 80 & 20,000 & 181.2 & 3683.1 & 0.049 & $1(8)+3(2)$ & 0.275 \\
\hline & & 30,000 & 270.5 & 5546.5 & 0.049 & $1(5)$ & \\
\hline & 100 & 20,000 & 179.3 & 3697.7 & 0.048 & $1(8)+3(2)$ & 0.275 \\
\hline & & 30,000 & 245.4 & 5010.2 & 0.049 & 1(6) & \\
\hline & 20 & 20,000 & 163.9 & 3340.1 & 0.049 & $1(8)+3(3)$ & 0.296 \\
\hline & & 30,000 & 237.9 & 4906.9 & 0.048 & $1(7)$ & \\
\hline & 40 & 20,000 & 158.6 & 3271.3 & 0.048 & $1(8)+3(4)$ & 0.321 \\
\hline 30 & & 30,000 & 230.4 & 4829.5 & 0.048 & $1(7)$ & \\
\hline 30 & 60 & 20,000 & 153.6 & 3220 & 0.048 & $1(8)+3(4)$ & 0.321 \\
\hline & & 30,000 & 225.4 & 4726.2 & 0.048 & $1(7)$ & \\
\hline & 80 & 20,000 & 150.1 & 3150.8 & 0.048 & $1(8)+3(4)$ & 0.321 \\
\hline & & 30,000 & 219.1 & 4700.3 & 0.047 & $1(8)$ & \\
\hline & 100 & 20,000 & 145.1 & 3135.5 & 0.046 & $1(8)+3(5)$ & 0.356 \\
\hline
\end{tabular}




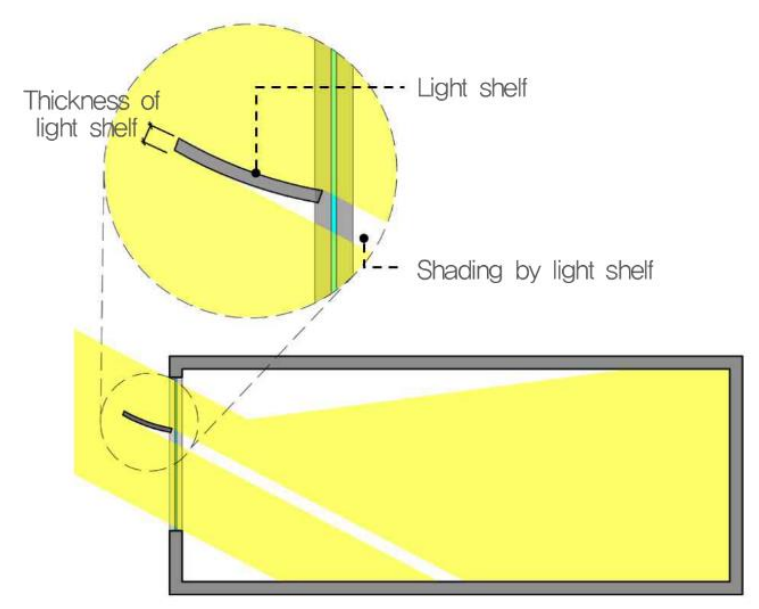

a) Inflow of light by a curved light shelf with an arc angle of $20^{\circ}$

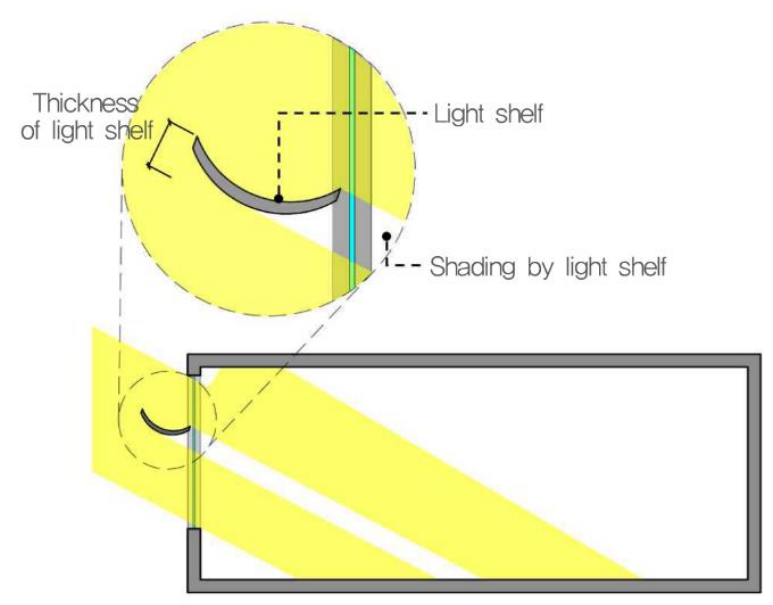

b) Inflow of light by a curved light shelf with an arc angle of $100^{\circ}$

Figure 17. Inflow of light versus the light shelf arc angle during winter.

In summary, the optimal specifications for a curved light shelf differed depending on the season, and therefore, optimal angle control was required, as in the case of a flat light shelf. However, unlike angle control, it was difficult to introduce the concept of control to the curvature of a light shelf. We thus calculated the consumption of lighting energy based on the curvature angle of the light shelf that best reduced the lighting energy consumption for arc angles of $20^{\circ}, 40^{\circ}, 60^{\circ}, 80^{\circ}$, and $100^{\circ}$, as shown in Table 11. The optimal curvature of a curved light shelf was thus found to be an arc angle of $60^{\circ}$, and the optimal light shelf angles were found to be $30^{\circ}, 30^{\circ}$, and $10^{\circ}$ for summer, mid-season, and winter, respectively. In addition, as shown in Table 12, a curved light shelf with a light shelf angle of $20^{\circ}$ was found to reduce lighting energy consumption by 3.6\% from a base level of $1.355 \mathrm{kWh}$, which was the sum of the lighting energy consumption and the operating energy associated with a movable flat light shelf.

Table 11. Lighting energy consumption versus arc angle and angle control.

\begin{tabular}{ccc}
\hline & Light Shelf & \\
Arc Angle & $\begin{array}{c}\text { Angle Control } \\
\text { Lighting Energy Consumption (kWh) } \\
\text { (Summer/Mid-Season/Winter) }\end{array}$ \\
\hline 20 & $30^{\circ} / 30^{\circ} / 20^{\circ}$ & \\
40 & $30^{\circ} / 30^{\circ} / 10^{\circ}$ & 1.306 \\
60 & $30^{\circ} / 30^{\circ} / 10^{\circ}$ & 1.281 \\
80 & $30^{\circ} / 30^{\circ} / 0^{\circ}$ & 1.252 \\
100 & $30^{\circ} / 30^{\circ} / 10^{\circ}$ & 1.331 \\
& & 1.343 \\
\hline
\end{tabular}

Table 12. Lighting energy consumption by fixed light shelf with an arc angle of $60^{\circ}$.

\begin{tabular}{cccc}
\hline Light Shelf Angle & $\begin{array}{c}\text { Lighting Energy } \\
\text { Consumption }\end{array}$ & Light Shelf Angle & $\begin{array}{c}\text { Lighting Energy } \\
\text { Consumption (kWh) }\end{array}$ \\
\hline-10 & 1.447 & 20 & 1.306 \\
0 & 1.355 & 30 & 1.310 \\
10 & 1.355 & - & - \\
\hline
\end{tabular}

This finding shows that lighting energy consumption can be reduced by optimizing the shape of the light shelf reflector, without any operation such as angle control required to improve the daylighting efficiency. Fixed curved light shelves have advantages over movable flat light shelves in terms of 
reduced installation costs and ease of maintenance. This demonstrates that curvature improves the reduction in lighting energy consumption achieved by light shelves significantly.

\section{Conclusions}

This study focused on the application of light shelves to reduce lighting energy in the building sector and proposed a curved light shelf to improve the daylighting performance of conventional light shelves. We analyzed the reduction in lighting energy and the indoor uniformity ratio according to the curvature of a curved light shelf using a test bed to examine its effectiveness and derive the optimal specifications. The key findings of this study are provided below.

The optimal specifications for a flat light shelf without curvature for reducing lighting energy consumption were found to be $30^{\circ}, 30^{\circ}$, and $20^{\circ}$ for summer, mid-season, and winter, respectively. However, a light shelf angle of $30^{\circ}$ was considered to be unsuitable for improving glare and the uniformity ratio in the mid-season, and thus, the optimal angles of flat light shelves in summer, mid-season, and winter were concluded to be $30^{\circ}, 20^{\circ}$, and $20^{\circ}$, respectively. This means that a movable light shelf that operates according to external environmental conditions is required to improve the daylighting performance of a light shelf.

The optimal arc angle for a curved light shelf during summer was found to be $60^{\circ}$, and an arc angle of $80^{\circ}$ or higher was found to be unsuitable for reducing lighting energy consumption. This is because a curved light shelf with an arc angle of $80^{\circ}$ reflects more natural light outward than it introduces into a room. In addition, a curved light shelf was found to be more effective in improving the indoor uniformity ratio than a flat light shelf during summer, and the optimal specifications for a curved light shelf during summer were found to be a light shelf angle of $30^{\circ}$ and an arc angle of $60^{\circ}$.

A curved light shelf was effective in reducing lighting energy consumption during mid-season when the arc angle was $40^{\circ}$, and the indoor uniformity ratio was improved when the arc angle was less than $40^{\circ}$. In addition, a curved light shelf solved the problem of an uncomfortable glare and uniformity ratio even when the angle was $30^{\circ}$. In summary, the optimal parameter values for a curved light shelf during mid-season were found to be a light shelf angle of $30^{\circ}$ and an arc angle of $40^{\circ}$.

A curved light shelf was found to be ineffective in reducing lighting energy consumption, in comparison to a flat light shelf, during winter. However, some improvements can be made by adjusting the angle and the curvature of the light shelf. In addition, a curved light shelf with a light shelf angle of $-10^{\circ}$ and a curvature of $30^{\circ}$ degrades the indoor uniformity ratio, which should be considered in the design of light shelves. Based on these findings, the optimal specifications for a curved light shelf during winter were found to be a light shelf angle of $20^{\circ}$ and arc angles of $20^{\circ}, 40^{\circ}$, or $60^{\circ}$.

In summary, the optimal specifications for curved light shelves are different depending on the season, so proper angle control is required, as with flat light shelves. In addition, the optimal arc angle for improving the lighting energy consumption and indoor uniformity ratio of a curved light shelf was found to be $60^{\circ}$. The optimal specifications for a fixed-type curved light shelf were found to be a light shelf angle of $20^{\circ}$ and an arc angle of $60^{\circ}$. Based on these values, the consumption of lighting energy can be reduced by $3.6 \%$ relative to a movable flat light shelf. These results show that we can improve the daylighting performance of a fixed light shelf, which does not involve any operating costs, by changing the shape of the reflector.

This study not only demonstrates the daylighting performance of curved light shelves compared to conventional flat light shelves but also derives the optimal specifications for reducing lighting energy and improving indoor uniformity ratio. However, there are some limitations to this study in that the performance evaluation was carried out in an artificial environment with an artificial solar irradiation apparatus under specific environmental factors. Therefore, additional performance evaluation studies that consider various environmental factors and various types of light shelves, such as the external illuminance considering the time period and weather, various types of curvatures, and illuminance standards considering the types of workspaces, need to be considered in future research. Studies in 
conjunction with various daylighting and shading devices not limited to light shelves should also be performed to demonstrate the effectiveness of curved light shelves.

Author Contributions: H.L. developed the main idea for the current study. H.L. and J.S. performed the analysis, interpreted the results, and wrote the manuscript. C.-h.C. reviewed the paper. All authors have read and approved the final manuscript.

Funding: This work was supported by a National Research Foundation of Korea (NRF) grant funded by the Korean government (MSIT) (Grant Number NRF-2018R1C1B4A01018660). The research was conducted with research grant support from Kwangwoon University in 2018.

Conflicts of Interest: The authors declare no conflict of interest.

\section{References}

1. Choi, W.J.; Joo, H.J.; Park, J.W.; Kim, S.K.; Lee, J.B. Power generation performance of building-integrated photovoltaic systems in a zero energy building. Energies 2019, 12, 2471. [CrossRef]

2. Global Alliance for Buildings and Construction. Global Status Report. Global Alliance for Buildings and Construction; UN Environment: Paris, France, 2017.

3. Kampelis, N.; Sifakis, N.; Kolokotsa, D.; Gobakis, K.; Kalaitzakis, K.; Isidori, D.; Cristalli, C. HVAC Optimization genetic algorithm for industrial near-zero-energy building demand response. Energies 2019, 12, 2177. [CrossRef]

4. Domjan, S.; Arkar, C.; Begelj, Ž.; Medved, S. Evolution of all-glass nearly zero energy buildings with respect to the local climate and free-cooling techniques. Build. Environ. 2019, 160, 6183. [CrossRef]

5. 2016 Renewable Energy Data Book. Available online: https://www.energy.gov/eere/analysis/downloads/ 2016-renewable-energy-data-book (accessed on 14 August 2018).

6. Lee, H.; Park, S.; Seo, J. Development and performance evaluation of light shelves using width-adjustable reflectors. Adv. Civ. Eng. 2018, 2018, 8065. [CrossRef]

7. Soler, A.; Oteiza, P. Light shelf performance in Madrid, Spain. Build. Environ. 1997, 32, 87-93. [CrossRef]

8. Lee, H.; Gim, S.H.; Seo, J.; Kim, Y. Study on movable light-shelf system with location-awareness technology for lighting energy saving. Indoor Built Environ. 2017, 26, 796-812. [CrossRef]

9. Lee, H.; Kim, S.; Seo, J. Evaluation of a light shelf based on energy consumption for lighting and air conditioning. Indoor Built Environ. 2018, 27, 1405-1414. [CrossRef]

10. Kim, K.; Lee, H.; Jang, H.; Park, C.; Choi, C. Energy-saving performance of light shelves under the application of user-awareness technology and light-dimming control. Sustain. Cities Soc. 2019, 44, 582-596. [CrossRef]

11. Lee, H. Performance evaluation of a light shelf with a solar module based on the solar module attachment area. Build. Environ. 2019, 159, 6161. [CrossRef]

12. Lee, H.; Jang, H.I.; Seo, J. A preliminary study on the performance of an awning system with a built-in light shelf. Build. Environ. 2018, 131, 255-263. [CrossRef]

13. Moazzeni, M.; Ghiabaklou, Z. Investigating the influence of light shelf geometry parameters on daylight performance and visual comfort, a case study of educational space in Tehran, Iran. Buildings 2016, 6, 26. [CrossRef]

14. Warrier, G.A.; Raphael, B. Performance evaluation of light shelves. Energy Build. 2017, 140, 19-27. [CrossRef]

15. Claros, S.T.; Soler, A. Indoor daylight climate-influence of light shelf and model reflectance on light shelf performance in Madrid for hours with unit sunshine fraction. Build. Environ. 2002, 37, 587-598. [CrossRef]

16. Illuminating Engineering Society. The Lighting Handbook, 10th ed.; Illuminating Engineering Society (IES): New York, NY, USA, 2011.

17. ISZ 9110: 2010. Recommended Levels of Illumination; Japanese Industrial Standards Committee: Tokyo, Japan, 2010.

18. KSA 3011-2013. Recommended Levels of Illumination; The Korean Standards Association (KSA): Seoul, Korea, 1998.

19. Lee, H.; Choi, C.H.; Sung, M. Development of a dimming lighting control system using general illumination and location-awareness technology. Energies 2018, 11, 2999. [CrossRef]

20. Lim, Y.W.; Heng, C.Y.S. Dynamic internal light shelf for tropical daylighting in high-rise office buildings. Build. Environ. 2016, 106, 155-166. [CrossRef] 
21. Lee, H.; Choi, C.H.; Seo, J. Development of a wall module employing aircap layers. Energy Build. 2018, 177, 413-422. [CrossRef]

22. Lee, H.; Seo, J. Development of window-mounted air cap roller module. Energies 2018, 11, 1909. [CrossRef]

23. Jung, B.K.; Choi, A.S. An experimental study of the optimum spatial characteristics and location of photosensor for daylight responsive dimming systems. J. Korean Inst. Illum. Electr. Install. Eng. 2003, 17, 8-14. [CrossRef]

24. Lee, H.; Seo, J.; Kim, S. Improvement of light-shelf performance through the use of a diffusion sheet. Build. Environ. 2018, 144, 248-258. [CrossRef]

(C) 2019 by the authors. Licensee MDPI, Basel, Switzerland. This article is an open access article distributed under the terms and conditions of the Creative Commons Attribution (CC BY) license (http://creativecommons.org/licenses/by/4.0/). 